\title{
An Experimental Study on Properties of Concrete using RHA \& RFA as a Partial Replacement of Fine Aggregate \& Fly Ash as a Cement
}

\author{
Ritesh Vishwakarma1, Pratiksha Malviya² \\ ${ }_{1}^{1}$ M.Tech. Scholar, 2 Professor \\ Department of Civil Engineering, Millennium Institute of Technology \& Science, \\ Bhopal, Madhya Pradesh, India
}

\begin{abstract}
How to cite this paper: Ritesh Vishwakarma / Pratiksha Malviya "An Experimental Study on Properties of Concrete using RHA \& RFA as a Partial Replacement of Fine Aggregate \& Fly Ash as a Cement" Published in International Journal of Trend in Scientific Research and Development (ijtsrd),

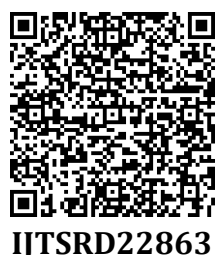
ISSN: 2456-6470, Volume-3 / Issue-3, April 2019, pp.377-379, URL: http://www.ijtsrd.com/papers/ijtsrd228 63.pdf

Copyright (C) 2019 by author(s) and International

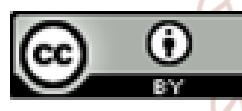
Journal of Trend in Scientific Research and Development Journal. This is an Open Access article distributed under the terms of the Creative Commons Attribution License (CC BY 4.0) (http://creativecommons.org/licenses/ by/4.0)

\section{ABSTRACT}

Concrete is the most widely used construction material in the world it is a mixture of cement, sand, coarse aggregate and water. Storage and safe disposal of industrial byproduct such as fly ash and RHA \& RFA is a huge problem everywhere, reuse of these waste eliminates/reduce the problem. In this experiment fine aggregate is replaced $0 \%, 6+6 \% \& 12+12 \%$, of its weight by RFA + RHA and cement is replaced $0 \%, 10 \%, 15 \%$ \& $20 \%$ of its weight by fly ash in all concrete mix and there effects are studied. In this experiment the compressive strength of the concrete is increased, It is found that the maximum strength increases with the replacement of cement and fine aggregate by fly ash at about $10 \%$ and $6 \%$ RHA \& 6\% RFA, after that compressive strength is decreases.

\section{INTRODUCTION}

Concrete is the most widely used construction material in the world it is a mixture of cement, sand, coarse aggregate and water. Cement is binding material in the cement concrete and its role is to provide strength to concrete. Cement fills up voids existing in the fine aggregate and makes the concrete impermeable. Provides strength to concrete on setting and hardening and binds the aggregate into a solid mass by virtue of its setting and hardening properties when mixed with water. Fine aggregate consist of small angular or rounded grains of silica. It is commonly used as the fine aggregate in cement concrete. It fills the voids existing in the coarse aggregate it reduces shrinkage cracking of concrete. It helps in hardening of cement by allowing the water through its voids. To form hard mass of silicates as it is believed that some chemical reaction take place between silica of sand and constituents of cement, Coarse aggregate makes solid and hard mass of concrete with cement and sand it increase the crushing strength of concrete.

Recycled fine aggregates are originated from the get ready of materials previously utilized as a part of an item and/or in construction. Examples include recycled fine aggregate concrete from construction and demolition waste material. Aggregate is one of the main ingredients in concrete. It covers more than $80 \%$ of the total volume of any concrete mix.

Rice husk ash is waste by itself has little cementitious value but in the presence of moisture it reacts chemically and forms cementitious compounds and attributes to the improvement of strength.

Fly ash remains in one of the deposits produced in the burning of coal, Fly cinder is for the most part caught shape the fireplaces of coal-terminated power plants and is one of two kinds of slag that together are known as coal powder.

\section{Objectives}

The objectives of the research are outlined below:

$>$ The general objectives of this dissertation work is to search out the properties of fresh and hardened concrete for M-35 grade of concrete for cement replacement at various percentages of $0 \%, 10 \%, 15 \%$ \& $20 \%$ by fly ash \& fine aggregate replacement at various percentages of $0 \%, 6+6 \%, \& 12+12 \%$ by RHA \& RFA 
International Journal of Trend in Scientific Research and Development (IJTSRD) @ www.ijtsrd.com eISSN: 2456-6470

Table No.1: Samples Details for M-35 Grade Concrete

\begin{tabular}{|c|c|c|c|c|c|c|c|}
\hline Mix(M35) & S-1 & S-2 & S-3 & S-4 & S-5 & S-6 & S-7 \\
\hline FLY ASH (\%) & 0 & 10 & 15 & 20 & 10 & 15 & 20 \\
\hline RICE HUSK ASH (\%) & 0 & 6 & 6 & 6 & 12 & 12 & 12 \\
\hline RECYCLED FINE AGGREGATE (\%) & 0 & 6 & 6 & 6 & 12 & 12 & 12 \\
\hline
\end{tabular}

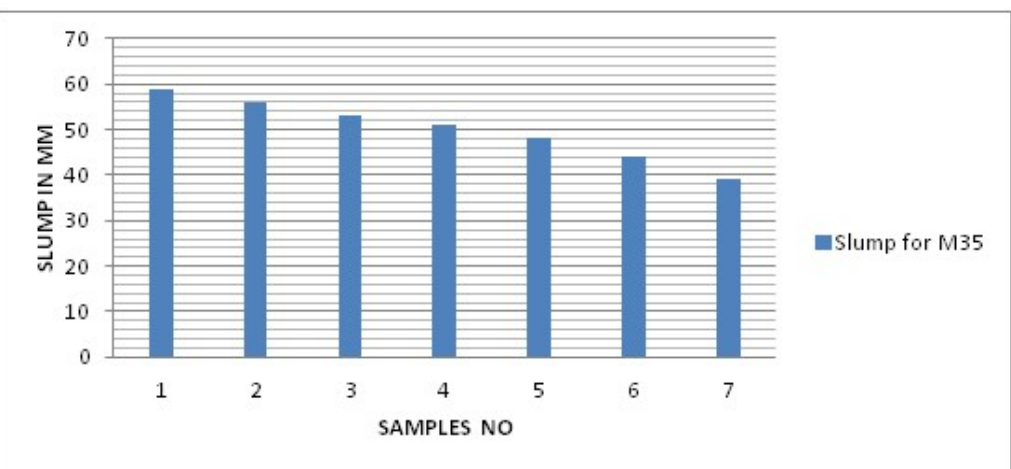

Figure 1 shows slump value with FA, RHA \& RFA for M-35

Table No.2: Slump value in mm for M-35 Grade Concrete

\begin{tabular}{|c|c|c|}
\hline \multicolumn{3}{|c|}{ SLUMP IN MM } \\
\hline SAMPLES NO. & Column1 & Slump for M35 \\
\hline 1 & S-1, FA 0\%,RHA 0 $\%$, RFA 0\% & 59 \\
\hline 2 & S-2, FA 10\%, RHA 6\%, RFA 6\% & 56 \\
\hline 3 & S-3, FA 15\%, RHA 6\%, RFA 6\% & 53 \\
\hline 4 & S-4, FA 20\%, RHA 6\%, RFA 6\% & 51 \\
\hline 5 & S-5, FA 10\%, RHA 12\%, RFA 12\% & 48 \\
\hline 6 & S-6, FA 15\%, RHA 12\%, RFA 12\% & 44 \\
\hline 7 & S-7, FA 20\%, RHA 12\%, RFA 12\% & 39 \\
\hline
\end{tabular}

Table No.3: Compressive Strength Variation for M-35 Grade Concrete

Compressive Strength of $\mathrm{M}-35$ grade concrete in $\mathrm{N} / \mathrm{mm} 2$

\begin{tabular}{|c|c|c|c|c|}
\hline SAMPLES NO. & Column1 & 7 days & 14 days & 28 days \\
\hline 1 & S-1, FA 0\%,RHA 0 $\%$, RFA 0\% & 30.12 & 39.9 & 44.2 \\
\hline 2 & S-2, FA 10\%, RHA 6\%, RFA 6\% & 33.42 & 44.9 & 49.7 \\
\hline 3 & S-3, FA 15\%, RHA 6\%, RFA 6\% & 32.83 & 44.6 & 49.3 \\
\hline 4 & S-4, FA 20\%, RHA 6\%, RFA 6\% & 32.33 & 44.2 & 48.3 \\
\hline 5 & S-5, FA $10 \%$, RHA $12 \%$, RFA $12 \%$ & 32.22 & 44.1 & 48.7 \\
\hline 6 & S-6, FA $15 \%$, RHA 12\%, RFA $12 \%$ & 32.12 & 43.2 & 48.3 \\
\hline 7 & S-7, FA $20 \%$, RHA $12 \%$, RFA $12 \%$ & 31.6 & 42.11 & 46.44 \\
\hline
\end{tabular}

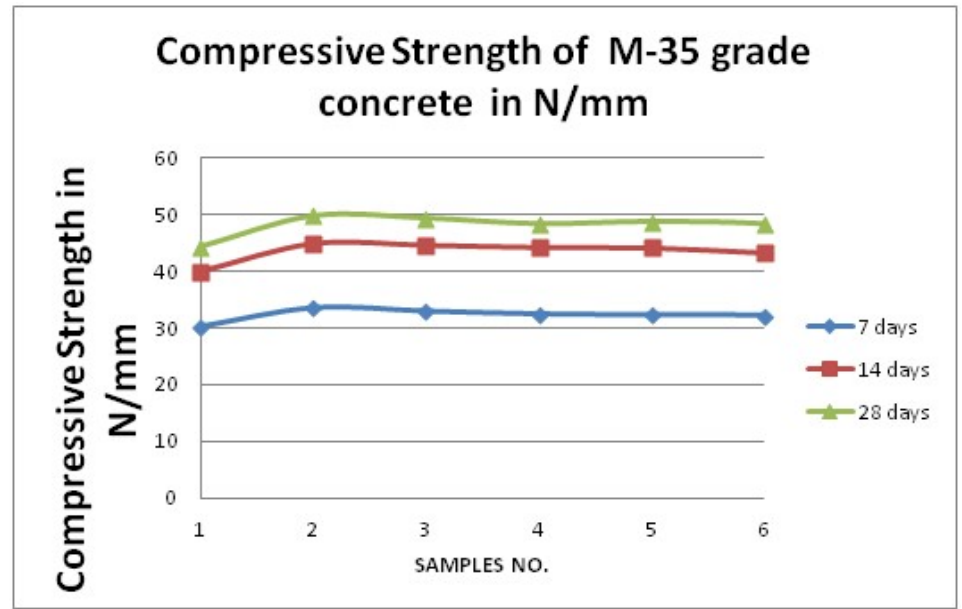

Figure 2 shows Compressive Strength of M35 Grade concrete

$>$ For M-35 the maximum 28 day compressive strength of nominal cube obtained was $44.2 \mathrm{~N} / \mathrm{mm}^{2}$, for a mix with RHA + RFA of $6+6 \% 49.72 \mathrm{~N} / \mathrm{mm}^{2}$ compressive strength is found.
$>$ An increase in strength over normal concrete is $12.45 \%$ when we added Fly ash, RHA \& RFA. 
It has been seen during experiments that as the percentage of RHA increases the compressive strength increases initially, on further increase in its percentage compressive strength will be reduced.

\section{Conclusions obtained by this study are as under -}

Compressive strength, of concrete based on controlled mix (fine aggregate is replaced by different percentage of RHA + RFA as $6+6 \%$ and $12+12 \%$ and cement replaced by three percentages of fly ash i.e. $10 \%, 15 \%$ and $20 \%$.) were higher than the normal Mix and concrete at all the ages. And also there is cost reduction for some extent.

It has been seen during experiments that as the percentage of RHA, RFA and fly ash increases the compressive strength increases initially, on further increase in its percentage reduces its compressive strength.

\section{REFERENCES}

[1] Abadi, M.H.S., Delbari, A., Fakoor, Z. \& Baedi, J., 2015. Effects of Annealing Temperature on Infrared Spectra of SiO2 Extracted From Rice Husk. J. Ceram. Sci. Tech., 06(01), pp. 41-46.

[2] Adam, F., Saraswathy, B. \& Wong, P.L., 2006. Rice Husk Ash Silica as a Support Material for Ruthenium Based Heterogenous Catalyst. Journal of Physical Science, Vol. 17(2), pp. 1-13.

[3] Ali, F. \& Al-Shawabkeh., 2015. Evaluation of the Potential Use of Waste Tires as Supplementary Fuel in Jordan Cement Industry. Council for Innovative Research.

[4] Ali, M.B., Saidur, R. \& Hossain, M.S., 2011. A Review on Emission Analysis in Cement Industries. Renewable and Sustainable Energy Reviews.

[5] Anderson, J.E., Wulfhorst, G. \& Lang, W., 2015. Energy Analysis of the built Environment-A Review and Outlook. Renewable and Sustainable Energy Reviews.

[6] Antiohos S.K., Papadakis V.G. \& Tsimas, S., 2014. Rice husk ash (RHA) effectiveness in cement and concrete as a function of reactive silica and fineness. Cement and Concrete Research.

[7] Aprianti, E., Shafigh, P., Bahri, S. \& FarahanI, J.N., 2014. Supplementary cementitious materials origin from agricultural wastes. Construction and Building Materials 74, pp. 176-187.

[8] Bie, R.S., Song, X.F., Liu, Q.Q. Ji, X.Y. \& Chen, P., 2014. Studies on effects of burning conditions and rice husk ash (RHA) blending amount on the mechanical behavior of cement. Cement \& Concrete Composites 55, pp. 162-168.

[9] British Standard Institution, 2009. BS EN 12350-2: 2009 Testing fresh concrete Part 2: Slump-test.

[10] British Standard Institution, 2002. BS EN 12390-3: 2002 Testing hardened concrete Part 3: Compressive strength of test specimens.

[11] British Standard Institution, 2004. BS EN 12504-4: 2004 Testing concrete Part 4: Determination of ultrasonic pulse velocity.

[12] Bui, D.D., Hu, J. \& Stroeven, P., 2005. Particle size effect on the strength of rice husk ash blended gap-graded Portland cement concrete. Cement and Concrete Composites. 27(3), pp. 357-366.

[13] Ciolacu, D., Ciolacu, F. \& Popa, V.I., 2010. Amorphous cellulose - structure and characterization. Cellulose Chemistry and Technology.

[14] Della, V.P., Kuhn, I. \& Hotza, D., 2002. Rice husk ash as an alternate source for active silica production. Materials Letters 57, pp. 818-821.

[15] Gambhir, M.L., 2013. Concrete Technology Fifth Edition. Published by McGraw Hill Education (India) Private Limited, P-24, Green Park Extention, New Delhi 110016.

[16] Ganesan, K., Rajagopal, K. \& Thangavel, K., 2007. Rice husk ash blended cement: Assessment of optimal level of replacement for strength and permeability properties of concrete. Construction and Building Materials.

17] Givi, A.N., Rashid, S.A., Aziz, F.N.A. \& Salleh, M.A.M., 2010. Contribution of Rice Husk Ash to the Properties of Mortar and Concrete. Journal of American Science.

[18] Global Construction Perspectives, 2015.Company PDF Report. [Online] Available at: http://www.globalconstruction2025.com/uk/compan y-pdf-report.html [Accessed 25 March 2015].

[19] Guneyisia, E., Ozturanb, T. \& Gesoglu, M., 2007. Effect of initial curing on chloride ingress and corrosion resistance characteristics of concretes made

[20] With plain and blended cements. Building and Environment. 42(7), pp. 2676-2685.

[21] Food and Agriculture Organization of the United Nations (FAO), 2015. FAO statistics division, Crops production of Malaysia. [Online] Available at: http://faostat3.fao.org/download/Q/QC/E [Accessed 19 March 2015]. 